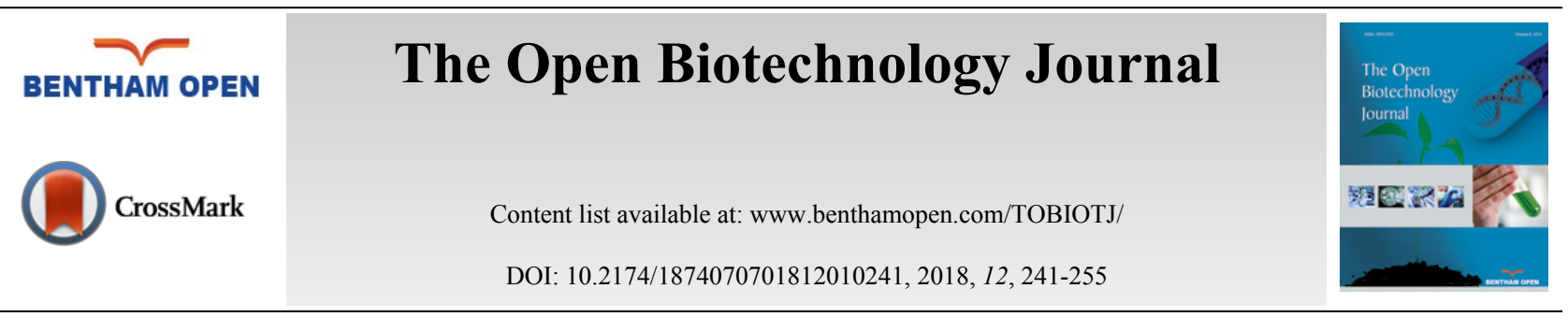

REVIEW ARTICLE

\title{
A Review of Three-dimensional Printing for Biomedical and Tissue Engineering Applications
}

\author{
M. Gundhavi Devi ${ }^{1}$, M. Amutheesan ${ }^{2}$, R. Govindhan ${ }^{3}$ and B. Karthikeyan, \\ ${ }^{\prime}$ Centre for Bioscience and Nanoscience Research, Coimbatore, Tamil Nadu 641021, India \\ ${ }^{2}$ Department of Aeronautical Engineering, Hindustan Institute of Technology \& Science, Padur, Chennai, Tamil Nadu \\ 603103, India \\ ${ }^{3}$ Department of Chemistry, Annamalai University, Annamalai Nagar, Tamil Nadu 608 002, India
}

Received: June 21, 2018

Revised: July 22, 2018

Accepted: September 7, 2018

\begin{abstract}
:
Background:

Various living organisms especially endangered species are affected due to the damaged body parts or organs. For organ replacement, finding the customized organs within the time by satisfying biomedical needs is the risk factor in the medicinal field.

\section{Methods:}

The production of living parts based on the highly sensitive biomedical demands can be done by the integration of technical knowledge of Chemistry, Biology and Engineering. The integration of highly porous Biomedical CAD design and 3D bioprinting technique by maintaining the suitable environment for living cells can be especially done through well-known techniques: Stereolithography, Fused Deposition Modeling, Selective Laser Sintering and Inkjet printing are majorly discussed to get final products.
\end{abstract}

\section{Results:}

Among the various techniques, Biomedical CAD design and 3D printing techniques provide highly precise and interconnected 3D structure based on patient customized needs in a short period of time with less consumption of work.

\section{Conclusion:}

In this review, biomedical development on complex design and highly interconnected production of 3D biomaterials through suitable printing technique are clearly reported.

Keywords: 3D bioprinting, 3D scaffold, Biomedical, Tissue engineering, Polymer, Rapid prototyping.

\section{INTRODUCTION}

Three-dimensional printing was first patented in 1986 by Charles Hull for Stereolithography Apparatus (SLA). Early researchers are known as Rapid prototyping technologies. Later, stereolithography is commonly known as 3D printing. 3D printing was initially used to create prototypes for product development within certain industries. Dr. Hideo, a Japanese lawyer was the first person to file a patent for rapid prototyping technology. Charles (chuck) Hull was the first person to invent the stereolithography machine (3D printer), which was the first ever device of its kind to print a real physical part from a digital (computer) generated file [1,2]. Three-dimensional printing technology is one of the trending additive manufacturing methods. It is a process of making a 3D object by adding layer-by-layer of

\footnotetext{
"Address correspondence to this author at the Department of Chemistry, Annamalai University, Annamalai Nagar 608 002, Tamil Nadu, India; Tel: +91 9842491114; E-mail: bkarthi_au@yahoo.com
} 
required material using a three-dimensional digital model [3, 4]. The most commonly used core material for additive manufacturing includes ceramic, metal, plastic and polymers (synthetic or natural polymers) [5 - 7]. 3D objects are mainly formed under the efficient control of digital computer, 3D modeling software (computer aided design or computer tomography scan images), machine equipment and layering materials [8]. Stereolithography is one of the commonly used software file types that is used for 3D printing [9]. After the given CAD model, 3D printing reads the input data from 3D modeling software. Finally, the highly sophisticated 3D objects are manufactured, which can easily produce tedious shapes and structures [10]. The three-dimensional printing process is shown step-by-step in Scheme $\mathbf{1}$.

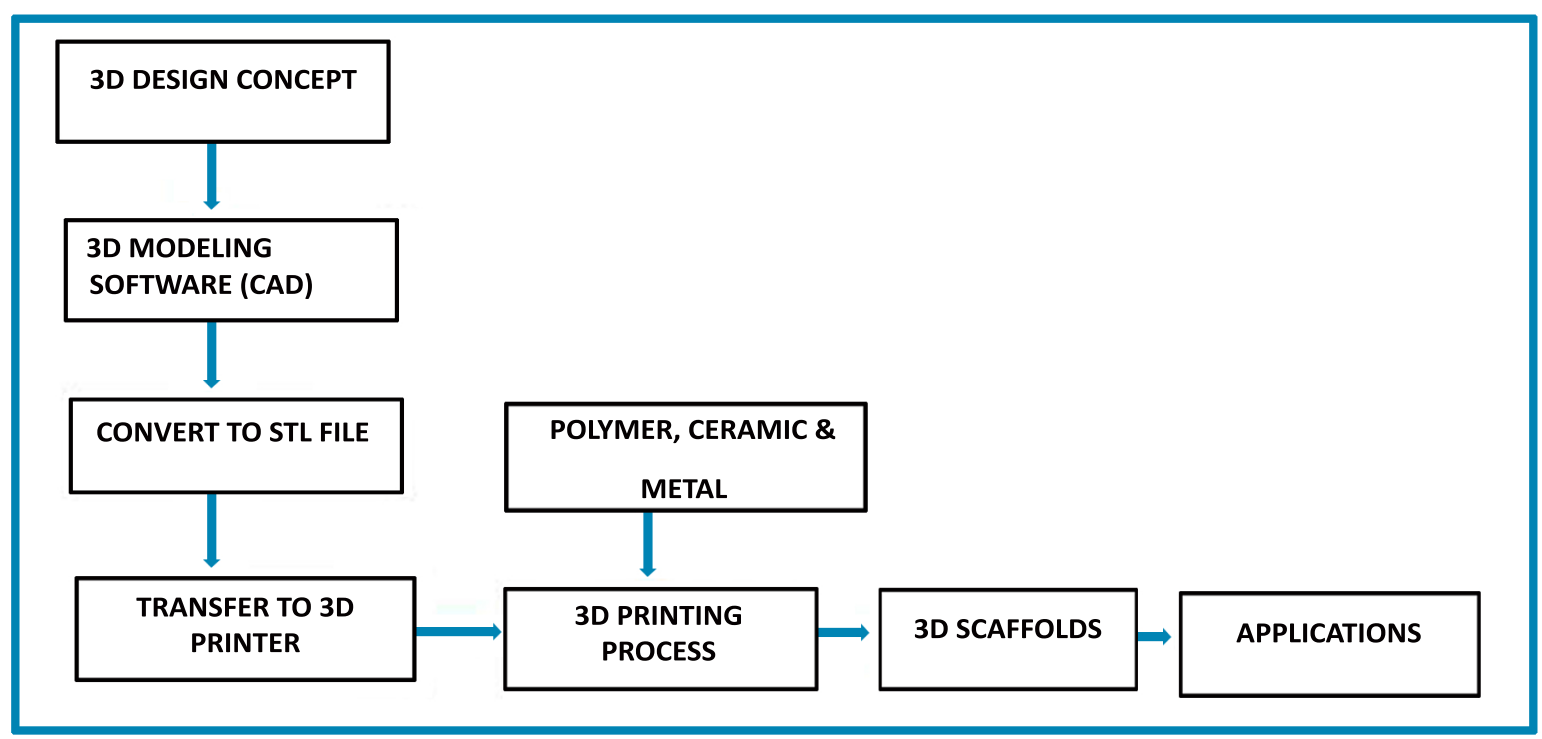

Scheme (1). Schematic process of three-dimensional printing.

Typically, many additive manufacturing processes are available in industries, laboratories, etc. It majorly integrated several fine parts such as vat photopolymerization, material extrusion, powder bed fusion, binder jetting, as shown in Table 1. Stereo-lithography (SLA) comes under the basics of vat photo-polymerization method [11, 12]. It is widely recognized as a first $3 \mathrm{D}$ printing method. SLA is a laser-based process, which mainly works with photopolymer resins to form a solid 3D object. In this process, photopolymer resin is finely placed in a VAT with a movable platform inside. A laser beam is sharply focused on the surface of the resin, and 3D structures are formed using CAD. Stereolithography is one of the most significant 3D printing processes with the good surface finish. Digital light processing is also depending on VAT photopolymerization. The huge difference between them is the light source, and it produces highly accurate parts with excellent resolution. The most widely used method in the material extrusion process is the Fused Deposition Modeling (FDM) or Fused Filament Fabrication (FFF) method. Fused Deposition Modeling uses continuous thermoplastic filament as the printing material to form fine structures and scaffolds [13 - 15]. In this process, it works by melting plastic filament in nozzle head and precisely deposit in build platform to form 3D structure according to the 3D data supplied to the printer. FDM process needs support structures for various bio-applications with overhanging geometries. FDM process is a highly accurate and reliable process that is studio-friendly. In the powder bed fusion process, the most widely used method is the Selective Laser Sintering (SLS) technique for scaffold fabrication. SLS is an additive manufacturing technique, which uses high power laser as a power source to sinter powdered material to fabricate various 3D scaffolds by 3D model [16, 17]. The significant material used in SLS are plastic, metal, ceramic, glass powders. SLS has the potential for creating prototypes, scaffolds, models and even final products, and it is mostly utilized in industry and all medical fields. It provides highly complex parts with adequate interior components and is the fastest Additive Manufacturing (AM) process for printing three-dimensional functional parts and organs with designed structural integrity. In Inkjet printing, the material being jetted is a binder, and it selectively drops into powdered bed of the part material to fuse for creating three-dimensional objects and scaffolds for various medical applications. A range of different materials can be used for three-dimensional printing for various fabrications $[18,19]$. Different areas of the scientific community combined to form a 3D structure, which is shown in Scheme 2. 
Table 1. Additive manufacturing technology.

\begin{tabular}{|c|c|c|}
\hline Methods & Classifications & Ref. \\
\hline Vat photopolymerization & i) Stereolithography (SLA) & $80-84$ \\
\hline Material extrusion & ii) Digital Light Processing (DLP) & $97-99$ \\
\hline Powder bed fusion & i) Fused Deposition Modeling (FDM) & $112-114$ \\
\hline Binder jetting & i) Selective Laser Sintering & 122 \\
\hline
\end{tabular}

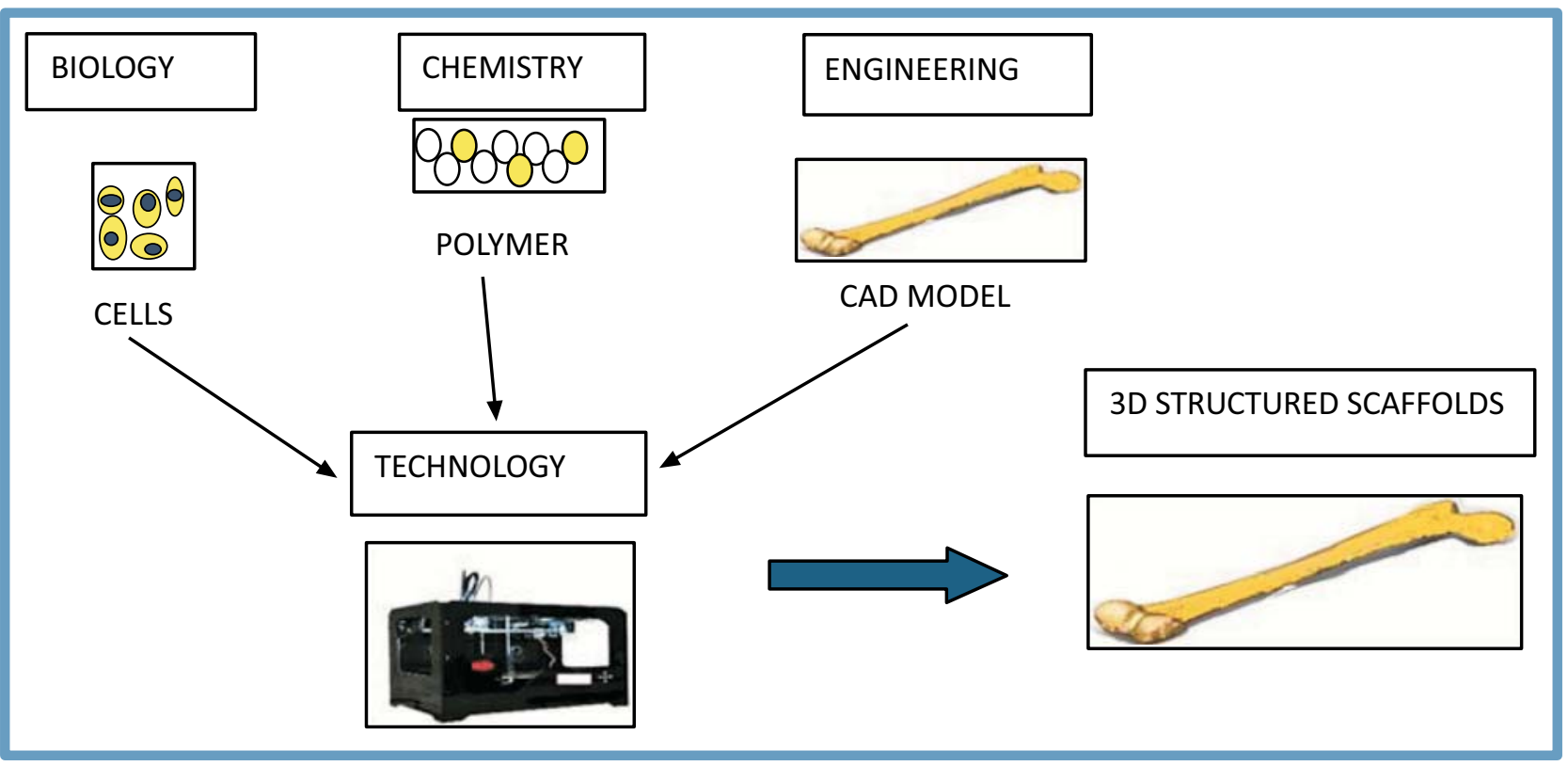

Scheme (2). A typical schematic workflow of multidisciplinary subjects used in the 3D printing method for tissue engineering applications.

3D file of the object can be created using Biomedical CAD software, with a 3D scanner. The variety of materials can be used for printing purposes such as plastics, alumide, ceramics, resins, metals, sand, textiles, biomaterials, glass, food and even lunar dust. Fused Deposition Modeling and Selective Laser Sintering use plastic and alumide for fabricating 3D scaffolds. Some FDM printers have two or more print heads to print multiple variable colors in scaffolds. Selective Laser Sintering consists of fabrication of 3D object by melting successive layers of powder together to form a scaffold. Stereolithography and Digital Light Processing use photopolymerization for developing highly sophisticated 3D products [20,21]. 3D printing is excellent for developing healthcare products in many ways, including implantable and non-implantable medical devices along with cost-effective customizable devices, patient-specific products in orthopedics and maxillofacial surgery, fabricating human living tissue, prosthetics and accurate pre-op models for academic purpose. It is mainly helpful for fabricating different types of living tissues, recreating difficult bone disorders such as craniofacial disfigurement, hearing aids and dental delivery devices, which offer excellent visualization and great dimensional stability. 3D printing also creates medical fixtures, functional testing models, industrial design and end-use parts [22, 23].

Nowadays, the ultimate aim of tissue and organ engineering is to restore normal functions of living organs and tissues, regeneration, replacement of defective or injured organs and tissues using different technology. To achieve this aim amongst different technology, three-dimensional scaffolds are commonly used for biomedical, tissue engineering applications and all medical fields, which is made up of polymer (natural or synthetic polymers), metals, ceramics, etc. Three-dimensional Scaffolds provide several mandatory functions [24 - 26]. It creates an adequate internal pathway for the cell attachment and migration. It should transfer several growth factors, oxygen transport and waste product removal in 3D scaffolds [27, 28]. It must be biocompatible, good mechanical properties and keeps its shape and structure when the cells and tissue are growing [29 - 32]. Hence, 3D bioprinting technology is commonly used for controlling cell and tissue pattern to be retained viability and functionality of the cells inside the printed $3 \mathrm{D}$ structure using different 
biomaterials [33 - 35]. Many researchers have been studied development and improvement of the appropriate scaffold using 3D printing in tissue engineering applications. Advances developed by 3D printing enhance the ability to control pore volume, pore size, and pore interconnectivity in $3 \mathrm{D}$ scaffolds for patient specific applications. In addition, materials used in a $3 \mathrm{D}$ printing machine, which is very essential for fabricating $3 \mathrm{D}$ scaffolds using $3 \mathrm{D}$ modeling software and scan data. 3D bioprinting process uses living cells and bioactive molecules in biomaterials, which produces a 3D structure that does not affect the viability and functionality of the cells [36, 37].

In future, researchers should be considered in the biomaterials such as bio-ink for creating $3 \mathrm{D}$ objects in tissue engineering applications and all the medical fields. Recent advancement in the biomedical field of stem cell development can be approached to the Bio3D printing cells fabrication techniques. It has the huge potential of studying disease modelling, discover drugs and mimicry of cellular components. The microfluidic approach in 3D tissue fabrication printing has garnered to a significant leap in the vascularization of biomedical engineering.3D printing technology can be evolved to cover the entire range of biomedical applications beginning from diagnosis and ending with prognosis. The potential of 3D printers can be exploited in the field of biomedical engineering such as research works, drug delivery, lab testing, clinical practice and helping the surgeons with as detailed mock surgeries as possible. $3 \mathrm{D}$ printing is used as a one-step solution for all the biomedical engineering problems [38 - 40].

Among different rapid prototyping technologies, the widely used four technologies for biomedical applications are stereolithography, fused deposition modeling, selective laser sintering and inkjet 3D printing [41 - 43]. Even though these techniques are used in various fields such as architectural modeling, art, lightweight machines, aircraft industry, defense field and medical fields, but it is excellent in tissue and other biomedical engineering applications [44 - 48]. Many researchers keep on improving various methods and materials to create 3D structure by satisfying the mechanical properties, biocompatibility for regeneration of normal tissues and bone regeneration, etc. [49, 50]. In this review, only few ongoing technologies are discussed, which can produce highly precise, greatly customized and extremely interconnected bio parts by satisfying all requirement of biomedical needs.

\section{THREE-DIMENSIONAL PRINTING FOR TISSUE ENGINEERING APPLICATION}

Three-dimensional printing technologies are an emerging technology to develop new tissues and organs [51 - 55]. Many researchers are currently conducting a study for fabricating 3D structure, which is useful for tissue engineering fields [56 - 60]. Three-dimensional bioprinting creates unique 3D structure, which controls cell proliferation, attachment and migration within 3D printed structures [61 - 65]. Therefore, different types of three-dimensional bioprinting techniques are used for a variety of tissue and organ engineering applications [66 - 70]. Herein, we will discuss the four different types of three-dimensional bioprinting methods, which are most commonly used methods such as Stereolithography and Digital Light Processing in Vat Photopolymerization, Fused Deposition Modeling in material extrusion, Selective Laser Sintering in powder bed fusion and Inkjet printing in binder jetting methods. Table 2 represents some of the advantages and disadvantages of different $3 \mathrm{D}$ printing methods in tissue engineering applications.

Table 2. Additive manufacturing: Advantages and disadvantages.

\begin{tabular}{|c|c|c|c|c|}
\hline Methods & Advantages & Disadvantages & Materials & Ref. \\
\hline SLA, DLP & $\begin{array}{c}\text { Simple and complex } \\
\text { Fast and good resolution }\end{array}$ & Expensive equipment and materials & PEG, PCL, PEGDA & {$[79-84]$} \\
\hline FDM & Easy to use good mechanical properties & $\begin{array}{c}\text { Filament required } \\
\text { Cannot used with cells }\end{array}$ & PCL, PLGA & [96-99] \\
\hline SLS & No need for support materials Various of biomaterials & $\begin{array}{c}\text { Rough surface } \\
\text { Expensive equipment }\end{array}$ & PCL/HA, PCL & {$[111-114]$} \\
\hline Inkjet & Cells and hydrogel printed, incorporation of drug and molecules & $\begin{array}{c}\text { Low resolution } \\
\text { Low mechanical properties }\end{array}$ & Fibrin, Gelatin & {$[121-122]$} \\
\hline
\end{tabular}

\subsection{Stereolithography (SLA)}

Stereolithography is also known as photo-solidification, which has been early and still widely used 3D printing method. SLA technique has commonly been used to fabricate 3D models, prototypes, patterns and production parts by using UV light in layer-by-layer. This technique has been obtained the patent by Charles (chuck) Hull in 1986 [71 - 73]. SLA method has the potential to create 3D scaffolds using photopolymerization. Similarly, the DLP technique has also been utilized to create 3D functional models and positive mold objects using visible light source [74, 75]. Both Stereolithography and DLP are formed on the vat photopolymerization [76 - 78]. In this process, UV light beam is 
directed onto the area of vat filled with a liquid photopolymer. UV light makes chains of molecules to bind and form polymers. And those polymers are essentially focused to fabricate three-dimensional objects. However, Photopolymerization method is formed free radicals that can affect cell membrane, protein and nucleic acids. Using computer Aided manufacturing or computer Aided design, Stereolithography can make any design that can be fast and expensive [79 - 81]. A typical schematic of stereolithography technique is shown in Scheme 3. Many scientists obtained the SLA 3D product using various biomaterials in tissue engineering applications. Elomaa et al. fabricated cell-laden hydrogels constructs with biomimetic complexity for use in pharmaceutics, vascular and tissue engineering application. They reported that they used water-soluble methacrylated poly (ethylene glycol-co-depsipeptide) to synthesize and formed a biodegradable photocrosslinkable macromer for SLA [82]. Neiman's et al. created three-dimensional(3D) hydrogel scaffolds with open channels for post-seeding using photopolymerizable PEG in Stereolithography based method. They showed that structural and functional development of foster formation in 3D liver aggregates. The aim of this study was to develop a platform for drug toxicity study, liver pathophysiology and obtained micro perfusion flow within the open channels of this 3D hydrogel structure [83]. Justinas et al. utilized direct laser writing lithography to fabricate three-dimensional (3D) microstructured scaffolds for cartilage tissue engineering using ultrafast pulsed lasers. They reported that 3D microstructured scaffolds are excellent in spatial resolution, geometry complexity and hexagonal pore shaped hybrid organic and inorganic material micro-structured scaffold, which were fabricated using DLW technique in combining with Cho seeding [84]. Owen et al. created Polymerized High internal Phase Emulsions scaffolds using emulsion templating by combining with micro-stereolithography, which produces cell ingrowth, plasma penetration, tightly controlled and highly interconnected microporosity. Scaffolds constructed using two acrylate monomers with isobornyl acrylate and supported osteogenic differentiation of mesenchymal cells [85]. Du et al. created ceramic artificial bone scaffolds using stereolithography with acrylic resin, which produced correct external shape and internal architecture for bone tissue ingrowth [86]. Hang et al. produced a three-dimensional (3D) scaffold with desired architectures using Stereolithography (SLA) technique. They showed that they used two lentiviral gene constructs with human bone marrow-derived mesenchymal stem cells into a solution of photocrosslinkable gelatin, which was focused using visible light-based projection [87]. Main advantages of stereolithography in tissue engineering applications are fast speed, good resolution, easy to remove support materials, complex designs and fabrication of a simple, and the disadvantages in SLA are a limited range of photosensitive resin and polymers, expensive equipment and materials, cytotoxicity of uncured photoinitiator.

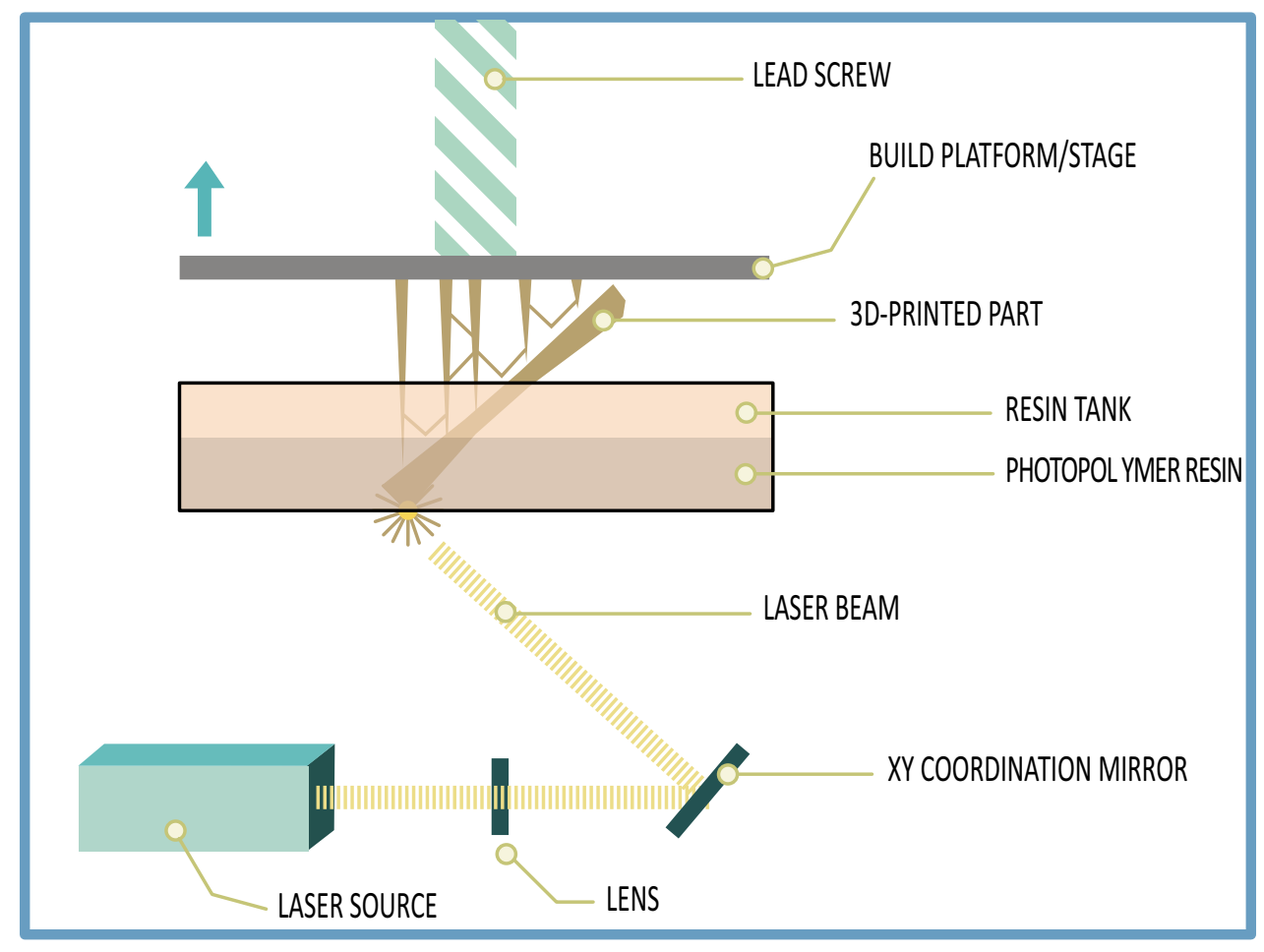

Scheme (3). A typical schematic representation of stereolithography. 


\subsection{Fused Deposition Modeling (FDM)}

FDM is known as Solid-based AM technology. It is also an Additive Manufacturing technology (AM) which is mainly used for modeling, prototyping and production applications [88 - 90]. Fused Deposition Modeling was developed and commercialized by Scott Crump and Stratasys, which works under the controlling of Stereolithography (STL) file [91 - 93]. In this process, FDM printers use a continuous filament of a thermoplastic material in a material extrusion method. These filaments are heated to the melting point temperature, and molten material from the printhead nozzle is deposited on the surface of the growing workpiece to create 3D structures [94]. The nozzle and substrate are controlled by computer to print defined shape and structure, and nozzle can be travelled in both horizontal and vertical directions. Using computer-aided technology, FDM is very flexible to print 3D objects [95 - 97]. FDM used the thermoplastics PLA, ABS, ABSi, polyphenylsulfone, polycarbonate and among others material. Fused Deposition Modeling is a thermal heating technique, which is used for 3D scaffolds fabrication in tissue engineering applications. Many researchers were investigated using FDM method for tissue engineering applications. Pati et al. fabricated 3D printed scaffolds using a composite of polycaprolactone, polylactic-co-glycolic acid, $\beta$ - tricalcium phosphate and mineralized ECM laid by human nasal inferior turbinate tissue-derived mesenchymal stromal cells. They studied that they improve the biological functionality of 3D printed synthetic scaffolds to mimics bony microenvironment using Fused Filament Fabrication, and they develop cellular responses and drive osteogenesis of stem cells. Jensen et al. created a polycaprolactone (PCL) scaffold using the combination of Fused Deposition Modeling and thermal induced phase separation to create nanoporous structure in polycaprolactone (PCL) scaffold. They studied PCL3D scaffold to be an excellent osteoconduction and osteointegration [98]. Xu et al. fabricated polycaprolactone nano-HA and polycaprolactone (PCL) 3D artificial bones to mimic natural goat femurs using Computed Tomography-guided Fused Deposition Modeling. They reported that polycaprolactone (PCL)/HA 3D artificial bones scaffolds are excellent in cell biocompatibility, biodegradation ability and bone formation ability, good biomechanical properties that reduce the stress shielding effect [99]. Idaszek et al. created a ternary polycaprolactone (PCL) scaffold, which consists of polycaprolactone (PCL), TCP and PLGA using Fused Deposition Modeling. They evaluated mechanical characteristics, degradation kinetics and surface properties through in-vitro. They resulted that the introduction of PLGA improved the degradation rate and surface roughness [100]. Li et al. used the Fused Deposition Modeling technique to make a comparison between Ti cage and PCL-TCP scaffold as a spinal fusion cage. They reported that inferior fusion performance of the PCL-TCP scaffold at 6 months is similar to Ti cage at 12 months. In addition, PCL-TCP scaffold is resulted in better bone ingrowth and distribution compared to Ti cage [101]. The main advantages of Fused Deposition Modeling are easy operation and easy use, adequate mechanical properties, low cost, solvent is not required and various lay- down patterns and the disadvantages in Fused Deposition Modeling are materials in filament form (thermoplastics), low speed, cannot used with cells and tissues, high temperature and smooth surface.

\subsection{Selective Laser Sintering (SLS)}

Selective Laser Sintering is an additive manufacturing technique, which uses laser as a power source to form solid 3D scaffolds [102 - 104]. It is very similar to Direct Metal Laser Sintering. SLS was patented and developed in mid1980's by Carl Deckard and Joe Beaman. SLS uses high powered lasers, which is too expensive. In this process, high powered lasers selectively fuse powdered material using CAD file or Scan data to form 3D objects [105]. This process is printed various materials; plastic, metal, ceramic and polymers and their composites [106 - 108]. Moreover, the SLS technique does not require a separate feeder for support material. SLS technique is the ability to make highly complex geometry directly from digital CAD data [109 - 111]. A typical schematic of Selective Laser Sintering is shown in Scheme 4. Many researchers reported the SLS product using various biomaterials. In addition, SLS is used in tissue engineering applications as scaffolds from various biomaterials and their composites. Du et al. constructed threedimensional bone scaffolds in Selective Laser Sintering technique with uniform multi-scaled porosity, moderate mechanical properties and good biocompatibility using PCL microspheres, and polycaprolactone /hydroxyapatite composite microspheres are used as the basic building materials. They showed that SLS derived scaffolds are excellent in multiple stem cells behavior, promoting cell adhesion, supporting cell proliferation, inducing cell differentiation, histocompatibility and adequate mechanical features [112]. Chen et al. fabricated polycaprolactone scaffolds for cartilage tissue engineering in craniofacial reconstruction using Selective Laser Sintering technique, which was surface modified through immersion coating with either gelatin or collagen. They reported that surface modification with collagen or gelatin improved the hydrophilicity, water uptake and good mechanical strength [113]. Roskies et al. created polyetheretherketone scaffolds using Selective Laser Sintering technique with a computer-aided design program. They evaluated that PEEK scaffolds maintain the viability of adipose and bone marrow-derived MSCs and 
induce the osteodifferentiation of the adipose-derived MSCs [114]. Feng et al. created highly interconnected porous scaffolds with $\beta$-TCP doping of zinc oxide powder using Selective Laser Sintering technique. They studied that porous scaffold resulted in excellent mechanical and biological properties by evaluating fracture toughness, compressive strength, osteoinduction and osteoconduction [115]. Shuai et al. developed poly (vinyl alcohol)/calcium silicate composite scaffolds with interconnected porous structures and customized shapes using Selective Laser Sintering. They found excellent compressive strength, good bioactivity and cytocompatibility in these scaffolds [116]. The main advantages of Selective Laser Sintering are a wide range of materials, good mechanical strength, relatively high precision, high porosity, support materials not required, and the disadvantages of selective laser sintering are materials in powder form, difficult to remove trapped materials, expensive equipment and rough surface.

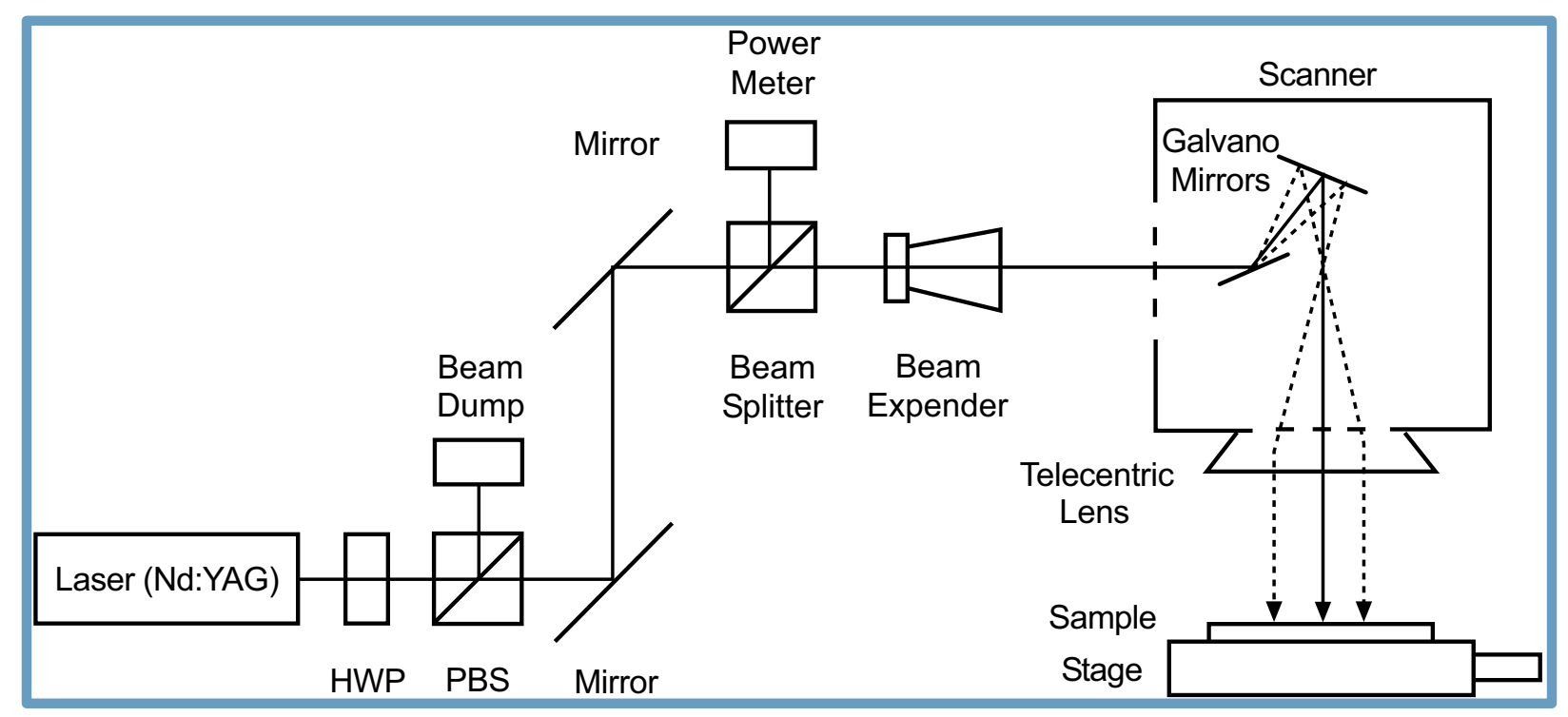

Scheme (4). A typical schematic representation of selective laser sintering.

\subsection{Inkjet 3D Printing}

Inkjet 3D printing technique is a rapid prototyping method, which is layered manufacturing technology for creating objects described by 3D modeling software and scan data [117]. Inkjet three-dimensional printing technique is similar to Inkjet head printing. In addition, Inkjet 3D printing method has the potential to use polymeric bio-inks for various applications such as Biomedical, Tissue engineering and all other Medical fields [118 - 120]. Nowadays, Inkjet bioprinter is a commonly used technology, which is useful for both non-biological and biological applications. Moreover, Inkjet bioprinter is a powerful technique for depositing cells, biomaterials and has become popular in creating cell-laden constructs, which can mimic the high complexity of native tissue and organ. A typical schematic of Inkjet bioprinting is shown in Scheme 5. Many scientists were investigated using Inkjet 3D printing in tissue and organ engineering applications. Lorber et al. fabricated Retinal Ganglion Cells (RGC) and glia using piezoelectric inkjet printing. They found that the viability and survival/growth of the cells in culture were not affected by the inkjet printing process [121]. Pati et al. printed dome-shaped adipose tissue using human decellularized adipose tissue matrix bio-ink, which encapsulates human adipose tissue-derived mesenchymal stem cells from the biomimetic approach. They evaluated the efficacy of their printed tissue constructs for adipose tissue regeneration [122]. Irvine et al. created a patterned 3D structure using Inkjet bioprinter and used printable gelatin as an ideal material crosslinked with microbial transglutaminase to print cell bearing hydrogel for three-dimensional constructs. They confirmed excellent cell affinity [123]. The main advantages of Inkjet 3D printing in tissue engineering applications are cells, tissues and hydrogel that can be printed, patient-customized fabrication, incorporation of drug and biomolecules, low cost and rapid production, and the disadvantages in Inkjet printing are a limitation of size, low resolution, low mechanical properties, using limited biomaterials. 


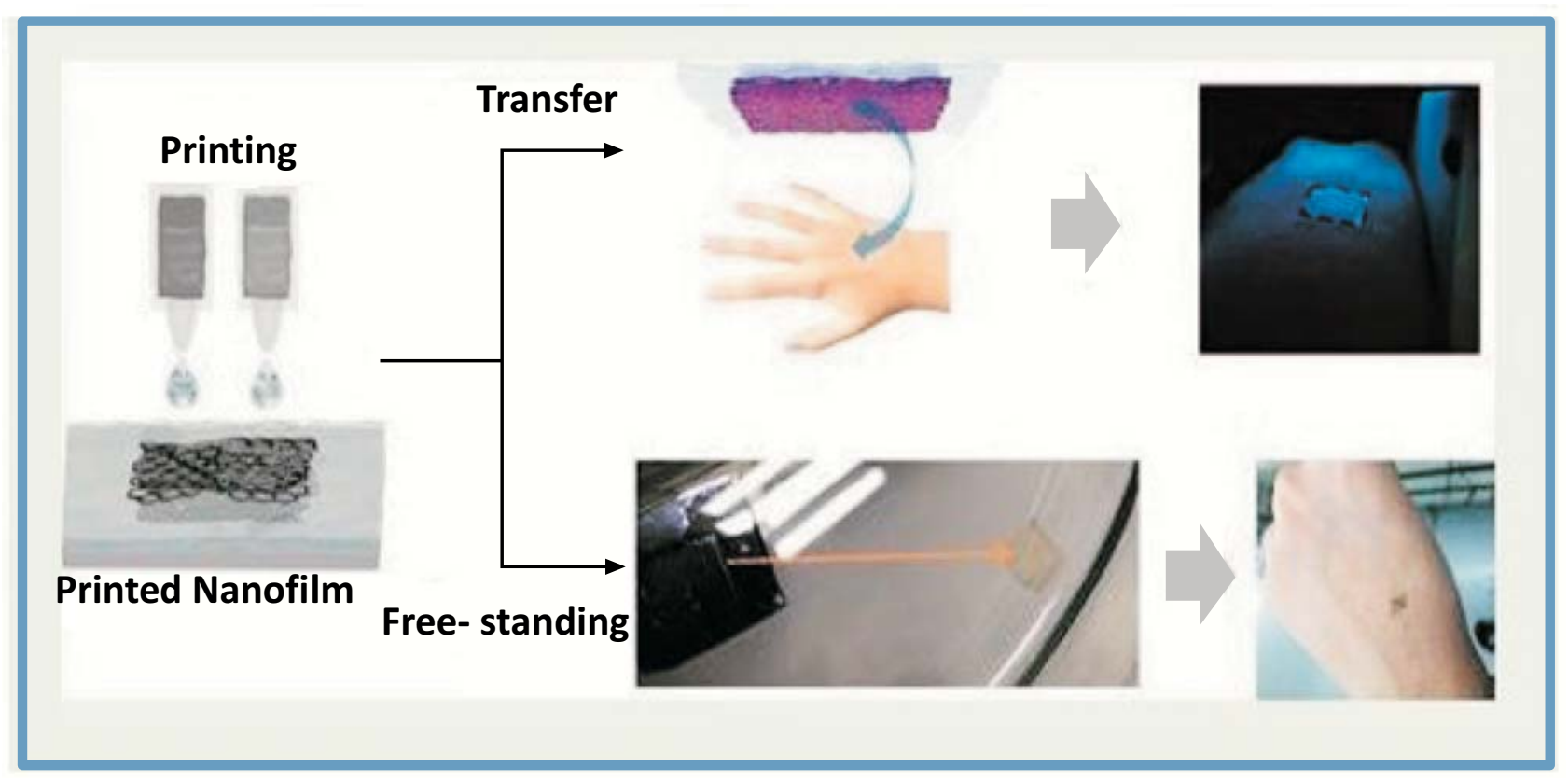

Scheme (5). A typical schematic representation of inkjet printing method.

\section{CONCLUSION AND FUTURE DIRECTION}

Rapid intellectual shine in the material science field uses nanoscopic materials for various societal applications: Nano Electronics, Tissue Engineering, Artificial Intelligence, etc. through various printing methodologies. SLA can be able to produce a high resolution of excellent surface finish products in a short period of time. The capability of using multiple prints heads provides choice to select different colors and materials on making the biomedical 3D products using FDM. SLS has the functionality to make highly complex geometry with more accuracy. Usage of bio-ink through ink jet printing open doors for a biomedical researcher for producing living cell products to satisfy the need of the rare species and other living organism. Biomedical researchers keep on working in Regenerative medicine. Self-healing property, natural Self-assembly of nanotubes and synergetic effect are the key factors in the artificial bio parts manufacturing. Natural Self-assembling property of the biocompatible peptide nanotubes can be able to reform its shape if the occurred damages in the 3D printed bio Parts are under the acceptable range of damages in biostructure like bone, tissues etc. This technique can be able to reduce the number of failure in the final products and minimize the requirement of design, production and overall cost. The precise designing using the Biomedical CAD software for customized design of tissue and organs for biomedical application, which can design the required 3D model. To manufacture the designed product, a unique combination of cells with the biopolymers can act as the core material for organs and tissues. The recent development of rapid prototyping process leads the manufacturing of living tissues and organs with highly porosity architecture. To obtain a highly efficient manufacturing model, the multifunctional 3D structure is undergoing recent development by combining more than two 3D printing technology or combination of 3D printing technology with other scaffold 3D printing technology. The quality of the functioning of the scaffold is mainly due to the integrity of design, materials and the manufacturing process. Improving biomaterials quality (Polymers and Bio-ink) is the most significant goal in Additive Manufacturing, which should be biocompatible, ease of processing, good mechanical properties for cell support and secure 3D structure. 3D printing also used for drug delivery, Chemical, Biological agents and Organ on-chip devices along with tissue engineering. The scientific community is now improving the resolution, speed of prototyping and quality of printing process by compatible with cells and tissues in 3D manufacturing. Patient customized 3D bioprinting is still a challengeable process of implementing for the whole global community. Moreover, the mimicking ability of the direct organ fabrication in the medical field is the goal of tissue engineering and regenerative medicine using 3D bioprinting. Fabrication of the scaffold for the mass bone defect is the crucial process in the 3D manufacturing due to unsatisfactory bone graft substitutes. The capability of integrating various disciplines: chemistry, materials science, computer-aided design, medical imaging and biomedical world should focus on to improve the availability of various models for different patient specific applications [124 - 126]. 


\section{CONSENT FOR PUBLICATION}

Not applicable.

\section{CONFLICT OF INTEREST}

The author declares no conflict of interest, financial or otherwise.

\section{ACKNOWLEDGEMENTS}

One of the authors, M. Gundhavi Devi would like to thank Prof. Insup Noh, Convergence institute of Biomedical and Biomaterials department, SEOUL TECH, Seoul, Korea for his valuable motivation to work on 3D-bioprinting.

\section{REFERENCES}

[1] Sithole MN, Kumar P, du Toit LC, Marimuthu T, Choonara YE, Pillay V. A 3D bioprinted in situ conjugated-co-fabricated scaffold for potential bone tissue engineering applications. J Biomed Mater Res A 2018; 106(5): 1311-21.

[http://dx.doi.org/10.1002/jbm.a.36333] [PMID: 29316290]

[2] Wang LL, Highley CB, Yeh YC, Galarraga JH, Uman S, Burdick JA. Three $\square$ dimensional extrusion bioprinting of single $\square$ and double $\square$ network hydrogels containing dynamic covalent crosslinks. J Biomed Mat Res A 2018; 106(4): 865-75.

[3] Placone JK, Engler AJ. Recent advances in extrusion-based 3D printing for biomedical applications. Adv Healthc Mater 2017. [http://dx.doi.org/10.1002/adhm.201701161] [PMID: 29283220]

[4] Kelly CN, Miller AT, Hollister SJ, Guldberg RE, Gall K. Design and structure-function characterization of 3d printed synthetic porous biomaterials for tissue engineering. Adv Healthc Mater 2018; 7(7): 1701095. [http://dx.doi.org/10.1002/adhm.201701095] [PMID: 29280325]

[5] Govindhan R, Karthikeyan B. Nano $\mathrm{Cu}$ interaction with single amino acid tyrosine derived self-assemblies; study through XRD, AFM, confocal Raman microscopy, SERS and DFT methods. J Phy Chem Sol 2017; 111: 123.: 34.

[http://dx.doi.org/111. 10.1016/j.jpcs.2017.07.025.]

[6] Gao G, Huang Y, Schilling AF, Hubbell K, Cui X. Organ bioprinting: Are we there yet? Adv Healthc Mater. Adv Healthc Mater 2018; 7(1): 1701018 .

[http://dx.doi.org/10.1002/adhm.201701018] [PMID: 29193879]

[7] Grémare A, Guduric V, Bareille R. Characterization of printed PLA scaffolds for bone tissue engineering. J Biomed Mat Res A 2018; 106(4): $887-7$.

[http://dx.doi.org/10.1002/jbm.a.36289.]

[8] Palaganas NB, Mangadlao JD, de Leon ACC, et al. 3D printing of photocurable cellulose nanocrystal composite for fabrication of complex architectures via stereolithography. ACS Appl Mater Interfaces 2017; 9(39): 34314-24.

[http://dx.doi.org/10.1021/acsami.7b09223] [PMID: 28876895]

[9] Badea A, McCracken JM, Tillmaand EG, et al. 3D-printed phema materials for topographical and biochemical modulation of dorsal root ganglion cell response. ACS Appl Mater Interfaces 2017; 9(36): 30318-28. [http://dx.doi.org/10.1021/acsami.7b06742] [PMID: 28813592]

[10] Cornelissen DJ, Faulkner-Jones A, Shu W. Current developments in 3D bioprinting for tissue engineering. Curr Opin Biomed Eng 2017; 2: 76-82. [http://dx.doi.org/10.1016/j.cobme.2017.05.004]

[11] Billiet T, Gevaert E, De Schryver T, Cornelissen M, Dubruel P. The 3D printing of gelatin methacrylamide cell-laden tissue-engineered constructs with high cell viability. Biomaterials 2014; 35(1): 49-62.

[http://dx.doi.org/10.1016/j.biomaterials.2013.09.078] [PMID: 24112804]

[12] Pekkanen AM, Mondschein RJ, Williams CB, Long TE. 3D printing polymers with supramolecular functionality for biological applications. Biomacromolecules 2017; 18(9): 2669-87. [http://dx.doi.org/10.1021/acs.biomac.7b00671] [PMID: 28762718]

[13] Bhargav A, Sanjairaj V, Rosa V, Feng LW, Fuh YH J. Applications of additive manufacturing in dentistry: A review. J Biomed Mater Res B Appl Biomater 2018; 106(5): 2058-64.

[http://dx.doi.org/10.1002/jbm.b.33961] [PMID: 28736923]

[14] Lim J, You M, Li J, Li Z. Emerging bone tissue engineering via Polyhydroxyalkanoate (PHA)-based scaffolds. Mater Sci Eng C 2017; 79: 917-29.

[http://dx.doi.org/10.1016/j.msec.2017.05.132] [PMID: 28629097]

[15] Gu BK, Choi DJ, Park SJ, Kim MS, Kang CM, Kim CH. 3-Dimensional bioprinting for tissue engineering applications. Biomater Res 2016; 20: 12 . [http://dx.doi.org/10.1186/s40824-016-0058-2] [PMID: 27114828]

[16] Sayyar S, Officer DL, Wallace GG. Fabrication of 3D structures from graphene-based biocomposites. J Mater Chem B Mater Biol Med 2017; 5: $3462-82$. 
[http://dx.doi.org/10.1039/C6TB02442D]

[17] Dumanli AG. Nanocellulose and its composites for biomedical applications. Curr Med Chem 2017; 24(5): $512-28$. [http://dx.doi.org/10.2174/0929867323666161014124008] [PMID: 27758719]

[18] Gao G, Cui X. Three-dimensional bioprinting in tissue engineering and regenerative medicine. Biotechnol Lett 2016; 38(2): $203-11$. [http://dx.doi.org/10.1007/s10529-015-1975-1] [PMID: 26466597]

[19] Bendtsen ST, Quinnell SP, Wei M. Development of a novel alginate-polyvinyl alcohol-hydroxyapatite hydrogel for 3D bioprinting bone tissue engineered scaffolds. J Biomed Mater Res A 2017; 105(5): 1457-68. [http://dx.doi.org/10.1002/jbm.a.36036] [PMID: 28187519]

[20] Chen C, Zhao ML, Zhang RK, et al. Collagen/heparin sulfate scaffolds fabricated by a 3D bioprinter improved mechanical properties and neurological function after spinal cord injury in rats. J Biomed Mater Res A 2017; 105(5): 1324-32. [http://dx.doi.org/10.1002/jbm.a.36011] [PMID: 28120511]

[21] Souness A, Zamboni F, Walker GM, Collins MN. Influence of scaffold design on 3D printed cell constructs. J Biomed Mater Res B Appl Biomater 2018; 106(2): 533-45. [http://dx.doi.org/10.1002/jbm.b.33863] [PMID: 28194931]

[22] Kim W, Lee H, Kim Y, et al. Versatile design of hydrogel-based scaffolds with manipulated pore structure for hard-tissue regeneration. Biomed Mater 2016; 11(5): 055002. [http://dx.doi.org/10.1088/1748-6041/11/5/055002] [PMID: 27586518]

[23] Wei D, Sun J, Bolderson J, et al. Continuous fabrication and assembly of spatial cell-laden fibers for a tissue-like construct via a photolithographic-based microfluidic chip. ACS Appl Mater Interfaces 2017; 9(17): 14606-17. [http://dx.doi.org/10.1021/acsami.7b00078] [PMID: 28157291]

[24] Muerza-Cascante ML, Shokoohmand A, Khosrotehrani K, et al. Endosteal-like extracellular matrix expression on melt electrospun written scaffolds. Acta Biomater 2017; 52: 145-58. [http://dx.doi.org/10.1016/j.actbio.2016.12.040] [PMID: 28017869]

[25] Hong N, Yang GH, Lee J, Kim G. 3D bioprinting and its in vivo applications. J Biomed Mater Res B Appl Biomater 2018; 106(1): 444-59. [http://dx.doi.org/10.1002/jbm.b.33826] [PMID: 28106947]

[26] Jo HH, Lee SJ, Park JS, et al. Characterization and preparation of three-dimensional-printed biocompatible scaffolds with highly porous strands. J Nanosci Nanotechnol 2016; 16: 11943-6. [http://dx.doi.org/10.1166/jnn.2016.13622]

[27] Lind JU, Busbee TA, Valentine AD, et al. Instrumented cardiac microphysiological devices via multimaterial three-dimensional printing. Nat Mater 2017; 16(3): 303-8. [http://dx.doi.org/10.1038/nmat4782] [PMID: 27775708]

[28] Jakus AE, Shah RN. Multi and mixed 3D-printing of graphene-hydroxyapatite hybrid materials for complex tissue engineering. J Biomed Mater Res A 2017; 105(1): 274-83. [http://dx.doi.org/10.1002/jbm.a.35684] [PMID: 26860782]

[29] Ozler SB, Bakirci E, Kucukgul C, Koc B. Three-dimensional direct cell bioprinting for tissue engineering. J Biomed Mater Res B Appl Biomater 2017; 105(8): 2530-44. [http://dx.doi.org/10.1002/jbm.b.33768] [PMID: 27689939]

[30] Zhu W, Ma X, Gou M, Mei D, Zhang K, Chen S. 3D printing of functional biomaterials for tissue engineering. Curr Opin Biotechnol 2016; 40: 103-12.

[http://dx.doi.org/10.1016/j.copbio.2016.03.014] [PMID: 27043763]

[31] Datta P, Ayan B, Ozbolat IT. Bioprinting for vascular and vascularized tissue biofabrication. Acta Biomater 2017; 51: 1-20. [http://dx.doi.org/10.1016/j.actbio.2017.01.035] [PMID: 28087487]

[32] Ouyang L, Highley CB, Rodell CB, Sun W, Burdick JA. 3D printing of shear-thinning hyaluronic acid hydrogels with secondary crosslinking. ACS Biomater Sci Eng 2016; 2: 1743-51. [http://dx.doi.org/10.1021/acsbiomaterials.6b00158]

[33] Zhao J, Swartz LA, Lin WF, et al. Three-dimensional nanoprinting via scanning probe lithography-delivered layer-by-layer deposition. ACS Nano 2016; 10(6): 5656-62. [http://dx.doi.org/10.1021/acsnano.6b01145] [PMID: 27203853]

[34] Morrison RJ, Kashlan KN, Flanangan CL, et al. Regulatory considerations in the design and manufacturing of implantable 3D-printed medical devices. Clin Transl Sci 2015; 8(5): 594-600. [http://dx.doi.org/10.1111/cts.12315] [PMID: 26243449]

[35] Valverde I. Three-dimensional printed cardiac models: Applications in the field of medical education, cardiovascular surgery, and structural heart interventions. Rev Esp Cardiol (Engl Ed) 2017; 70(4): 282-91. [http://dx.doi.org/10.1016/j.rec.2017.01.012] [PMID: 28189544]

[36] Das S, Pati F, Choi Y-J, et al. Bioprintable, cell-laden silk fibroin-gelatin hydrogel supporting multilineage differentiation of stem cells for fabrication of three-dimensional tissue constructs. Acta Biomater 2015; 11: 233-46. [http://dx.doi.org/10.1016/j.actbio.2014.09.023] [PMID: 25242654] 
[37] Jose RR, Rodriguez MJ, Dixon TA, Omenetto F, Kaplan DL. Evolution of bioinks and additive manufacturing technologies for 3D bioprinting. ACS Biomater Sci Eng 2016; 2: 1662-78. [http://dx.doi.org/10.1021/acsbiomaterials.6b00088]

[38] Xue C, Shi X, Fang X, et al. The "pure marriage" between 3D printing and well-ordered nanoarrays by using peald assisted hydrothermal surface engineering. ACS Appl Mater Interfaces 2016; 8(13): 8393-400. [http://dx.doi.org/10.1021/acsami.6b01417] [PMID: 26974545]

[39] Park JY, Choi Y-J, Shim J-H, Park JH, Cho DW. Development of a 3D cell printed structure as an alternative to autologs cartilage for auricular reconstruction. J Biomed Mater Res B Appl Biomater 2017; 105(5): 1016-28. [http://dx.doi.org/10.1002/jbm.b.33639] [PMID: 26922876]

[40] Kumar A, Nune KC, Misra RDK. Biological functionality of extracellular matrix-ornamented three-dimensional printed hydroxyapatite scaffolds. J Biomed Mater Res A 2016; 104(6): 1343-51. [http://dx.doi.org/10.1002/jbm.a.35664] [PMID: 26799466]

[41] Zhang M, Vora A, Han W, et al. Dual-responsive hydrogels for direct-write 3D printing. Macromolecules 2015; 48 : 6482-8. [http://dx.doi.org/10.1021/acs.macromol.5b01550]

[42] Gonçalves EM, Oliveira FJ, Silva RF, et al. Three-dimensional printed PCL-hydroxyapatite scaffolds filled with CNTs for bone cell growth stimulation. J Biomed Mater Res B Appl Biomater 2016; 104(6): 1210-9. [http://dx.doi.org/10.1002/jbm.b.33432] [PMID: 26089195]

[43] Xing JF, Zheng M-L, Duan X-M. Two-photon polymerization microfabrication of hydrogels: An advanced 3D printing technology for tissue engineering and drug delivery. Chem Soc Rev 2015; 44(15): 5031-9. [http://dx.doi.org/10.1039/C5CS00278H] [PMID: 25992492]

[44] Jakus AE, Secor EB, Rutz AL, Jordan SW, Hersam MC, Shah RN. Three-dimensional printing of high-content graphene scaffolds for electronic and biomedical applications. ACS Nano 2015; 9(4): 4636-48. [http://dx.doi.org/10.1021/acsnano.5b01179] [PMID: 25858670]

[45] Chia HN, Wu BM. Recent advances in 3D printing of biomaterials. J Biol Eng 2015; 9(1): 4. [http://dx.doi.org/10.1186/s13036-015-0001-4] [PMID: 25866560]

[46] Bandyopadhyay A, Bose S, Das S. 3D printing of biomaterials. MRS Bull 2015; 40: 108-15. [http://dx.doi.org/10.1557/mrs.2015.3]

[47] Nakayama Y, Takewa Y, Sumikura H, et al. In-body tissue-engineered aortic valve (Biovalve type VII) architecture based on 3D printer molding. J Biomed Mater Res B Appl Biomater 2015; 103(1): 1-11. [http://dx.doi.org/10.1002/jbm.b.33186] [PMID: 24764308]

[48] Temple JP, Hutton DL, Hung BP, et al. Engineering anatomically shaped vascularized bone grafts with hASCs and 3D-printed PCL scaffolds. J Biomed Mater Res A 2014; 102(12): 4317-25. [PMID: 24510413]

[49] Hung K-C, Tseng C-S, Hsu SH. Synthesis and 3D printing of biodegradable polyurethane elastomer by a water-based process for cartilage tissue engineering applications. Adv Healthc Mater 2014; 3(10): 1578-87.

[http://dx.doi.org/10.1002/adhm.201400018] [PMID: 24729580]

[50] Husár B, Hatzenbichler M, Mironov V, Liska R, Stampfl J, Ovsianikov A. Photopolymerization-based additive manufacturing for the development of 3D porous scaffolds. In Biomaterials for Bone Regeneration 2014; 149-201. [http://dx.doi.org/10.1533/9780857098104.2.149.]

[51] Vaezi M, Yang S. Freeform fabrication of nanobiomaterials using 3D printing.Rapid Prototyping of Biomaterials. Elsevier 2014; pp. 16-74. [http://dx.doi.org/10.1533/9780857097217.16]

[52] Gross BC, Erkal JL, Lockwood SY, Chen C, Spence DM. Evaluation of 3D printing and its potential impact on biotechnology and the chemical sciences. Anal Chem 2014; 86(7): 3240-53. [http://dx.doi.org/10.1021/ac403397r] [PMID: 24432804]

[53] Hribar KC, Soman P, Warner J, Chung P, Chen S. Light-assisted direct-write of 3D functional biomaterials. Lab Chip 2014; 14(2): 268-75. [http://dx.doi.org/10.1039/C3LC50634G] [PMID: 24257507]

[54] Duan B. State-of-the-Art review of 3D bioprinting for cardiovascular tissue engineering. Ann Biomed Eng 2017; 45(1): $195-209$. [http://dx.doi.org/10.1007/s10439-016-1607-5] [PMID: 27066785]

[55] Patra S, Young V. A review of 3D printing techniques and the future in biofabrication of bioprinted tissue. Cell Biochem Biophys 2016; 74(2): 93-8. [http://dx.doi.org/10.1007/s12013-016-0730-0] [PMID: 27193609]

[56] Garreta E, Oria R, Tarantino C, et al. Tissue engineering by decellularization and 3D bioprinting. Mater Today 2017; 20 : 166-78. [http://dx.doi.org/10.1016/j.mattod.2016.12.005]

[57] Kelly CN, Miller AT, Hollister SJ, Guldberg RE, Gall K. Design and structure-function characterization of 3D printed synthetic porous biomaterials for tissue engineering. Adv Healthc Mater 2017; 7(7): 1701095. [http://dx.doi.org/10.1002/adhm.201701095] [PMID: 29280325] 
[58] Alluri R, Jakus A, Bougioukli S, et al. 3D printed hyperelastic "bone" scaffolds and regional gene therapy: A novel approach to bone healing. J Biomed Mater Res A 2018; 106(4): 1104-10. [http://dx.doi.org/10.1002/jbm.a.36310] [PMID: 29266747]

[59] Richards D, Jia J, Yost M, Markwald R, Mei Y. 3D bioprinting for vascularized tissue fabrication. Ann Biomed Eng 2017; $45(1)$ : $132-47$. [http://dx.doi.org/10.1007/s10439-016-1653-z] [PMID: 27230253]

[60] Tan Z, Parisi C, Di Silvio L, Dini D, Forte AE. Cryogenic 3D printing of super soft hydrogels. Sci Rep 2017; 7(1): 16293. [http://dx.doi.org/10.1038/s41598-017-16668-9] [PMID: 29176756]

[61] Kim M, Kim W, Kim G. Topologically micropatterned collagen and poly( $\varepsilon$-caprolactone) struts fabricated using the poly(vinyl alcohol) fibrillation/leaching process to develop efficiently engineered skeletal muscle tissue. ACS Appl Mater Interfaces 2017; 9(50): 43459-69. [http://dx.doi.org/10.1021/acsami.7b14192] [PMID: 29171953]

[62] Blaeser A, Duarte Campos DF, Fischer H. 3D bioprinting of cell-laden hydrogels for advanced tissue engineering. Curr Opin Biomed Eng 2017; 2: 58-66. [http://dx.doi.org/10.1016/j.cobme.2017.04.003]

[63] Vella JB, Trombetta RP, Hoffman MD, Inzana J, Awad H, Benoit DSW. Three dimensional printed calcium phosphate and poly(caprolactone) composites with improved mechanical properties and preserved microstructure. J Biomed Mater Res A 2018; 106(3): 663-72. [http://dx.doi.org/10.1002/jbm.a.36270] [PMID: 29044984]

[64] McElheny C, Hayes D, Devireddy R. Design and fabrication of a low-cost three-dimensional bioprinter. J Med Device 2017; 11(4): 0410011-9.

[http://dx.doi.org/10.1115/1.4037259] [PMID: 29034057]

[65] Huh J, Lee J, Kim W, Yeo M, Kim G. Preparation and characterization of gelatin/ $\alpha$-TCP/SF biocomposite scaffold for bone tissue regeneration. Int J Biol Macromol 2018; 110: 488-96. [http://dx.doi.org/10.1016/j.ijbiomac.2017.09.030] [PMID: 28917939]

[66] Kuss MA, Wu S, Wang Y. Prevascularization of 3D printed bone scaffolds by bioactive hydrogels and cell co-culture. J Biomed Mater Res B Appl Biomater 2017; 106(5): 1788-98. [http://dx.doi.org/10.1002/jbm.b.33994] [PMID: 28901689]

[67] Tan Z, Liu T, Zhong J, Yang Y, Tan W. Control of cell growth on 3D-printed cell culture platforms for tissue engineering. J Biomed Mater Res A 2017; 105(12): 3281-92.

[http://dx.doi.org/10.1002/jbm.a.36188] [PMID: 28865175]

[68] Li L, Yu F, Shi J, et al. In situ repair of bone and cartilage defects using 3D scanning and 3D printing. Sci Rep 2017; 7(1): 9416. [http://dx.doi.org/10.1038/s41598-017-10060-3] [PMID: 28842703]

[69] Stephenson MK, Farris AL, Grayson WL. Recent advances in tissue engineering strategies for the treatment of joint damage. Curr Rheumatol Rep 2017; 19(8): 44. [http://dx.doi.org/10.1007/s11926-017-0671-7] [PMID: 28718059]

[70] Badea A, McCracken JM, Tillmaand EG, et al. 3D-printed pHEMA materials for topographical and biochemical modulation of dorsal root ganglion cell response. ACS Appl Mater Interfaces 2017; 9(36): 30318-28. [http://dx.doi.org/10.1021/acsami.7b06742] [PMID: 28813592]

[71] Li X, He J, Zhang W, Jiang N, Li D. Additive manufacturing of biomedical constructs with biomimetic structural organizations. Materials (Basel) 2016; 9(11): E909.

[http://dx.doi.org/10.3390/ma9110909] [PMID: 28774030]

[72] Chua CK, Yeong WY, An J. Special issue: 3D printing for biomedical engineering. Materials (Basel) $2017 ; 10(3)$ : E243. [http://dx.doi.org/10.3390/ma10030243] [PMID: 28772604]

[73] Gou M, Qu X, Zhu W, et al. Bio-inspired detoxification using 3D-printed hydrogel nanocomposites. Nat Commun 2014; 5: 3774. [http://dx.doi.org/10.1038/ncomms4774] [PMID: 24805923]

[74] De Santis R, D’Amora U, Russo T, Ronca A, Gloria A, Ambrosio L. 3D fibre deposition and stereolithography techniques for the design of multifunctional nanocomposite magnetic scaffolds. J Mater Sci Mater Med 2015; 26(10): 250. [http://dx.doi.org/10.1007/s10856-015-5582-4] [PMID: 26420041]

[75] Coelho RC, Marques AL, Oliveira SM. Extraction and characterization of collagen from Antarctic and Sub-Antarctic squid and its potential application in hybrid scaffolds for tissue engineering. 2017; 78: 787-95.

[76] Lee VK, Lanzi AM, Haygan N, Yoo S-S, Vincent PA, Dai G. Generation of multi-scale vascular network system within 3D hydrogel using 3D bio-printing technology. Cell Mol Bioeng 2014; 7(3): 460-72. [http://dx.doi.org/10.1007/s12195-014-0340-0] [PMID: 25484989]

[77] Gao G, Yonezawa T, Hubbell K, Dai G, Cui X. Inkjet-bioprinted acrylated peptides and peg hydrogel with human mesenchymal stem cells promote robust bone and cartilage formation with minimal printhead clogging. Biotechnol J 2015; 10(10): $1568-77$. [http://dx.doi.org/10.1002/biot.201400635] [PMID: 25641582]

[78] Kim T-H, Yun Y-P, Park Y-E, et al. In vitro and in vivo evaluation of bone formation using solid freeform fabrication-based bone morphogenic protein-2 releasing PCL/PLGA scaffolds. Biomed Mater 2014; 9(2): 025008. 
[http://dx.doi.org/10.1088/1748-6041/9/2/025008] [PMID: 24518200]

[79] Hong N, Yang G-H, Lee J, Kim G. 3D bioprinting and its in vivo applications. J Biomed Mater Res B Appl Biomater 2018; 106(1): 444-59. [http://dx.doi.org/10.1002/jbm.b.33826] [PMID: 28106947]

[80] Walker V. Implementing a 3D printing service in a biomedical library. J Med Libr Assoc 2017; 105(1): 55-60. [PMID: 28096747]

[81] Sochol RD, Gupta NR, Bonventre JV. A role for 3D printing in kidney-on-a-chip platforms. Curr Transplant Rep 2016; 3(1): 82-92. [http://dx.doi.org/10.1007/s40472-016-0085-x] [PMID: 28090431]

[82] Elomaa L, Pan CC, Shanjani Y, Malkovskiy A, Seppälä JV, Yang Y. Three-dimensional fabrication of cell-laden biodegradable poly(ethylene glycol-co-depsipeptide) hydrogels by visible light stereolithography. J Mater Chem B Mater Biol Med 2015; 3(42): 8348-58. [http://dx.doi.org/10.1039/C5TB01468A] [PMID: 29057076]

[83] Neiman JAS, Raman R, Chan V, et al. Photopatterning of hydrogel scaffolds coupled to filter materials using stereolithography for perfused 3D culture of hepatocytes. Biotechnol Bioeng 2015; 112(4): 777-87. [http://dx.doi.org/10.1002/bit.25494] [PMID: 25384798]

[84] Mačiulaitis J, Deveikytė M, Rekštytė S, et al. Preclinical study of SZ2080 material 3D microstructured scaffolds for cartilage tissue engineering made by femtosecond direct laser writing lithography. Biofabrication 2015; 7(1): 015015. [http://dx.doi.org/10.1088/1758-5090/7/1/015015] [PMID: 25797444]

[85] Owen R, Sherborne C, Paterson T, Green NH, Reilly GC, Claeyssens F. Emulsion templated scaffolds with tunable mechanical properties for bone tissue engineering. J Mech Behav Biomed Mater 2016; 54: 159-72. [http://dx.doi.org/10.1016/j.jmbbm.2015.09.019] [PMID: 26458114]

[86] Du D, Asaoka T, Ushida T, Furukawa KS. Fabrication and perfusion culture of anatomically shaped artificial bone using stereolithography. Biofabrication 2014; 6(4): 045002. [http://dx.doi.org/10.1088/1758-5082/6/4/045002] [PMID: 25215543]

[87] Lin H, Tang Y, Lozito TP, et al. Projection stereolithographic fabrication of BMP-2 gene-activated matrix for bone tissue engineering. Sci Rep 2017; 7(1): 11327.

[http://dx.doi.org/10.1038/s41598-017-11051-0] [PMID: 28900122]

[88] Zhang C, Bills BJ, Manicke NE. Rapid prototyping using 3D printing in bioanalytical research. Bioanalysis 2017; 9(4): 329-31. [http://dx.doi.org/10.4155/bio-2016-0293] [PMID: 28071134]

[89] Tonsomboon K, Butcher AL, Oyen ML. Strong and tough nanofibrous hydrogel composites based on biomimetic principles. Mater Sci Eng C 2017; 72: 220-7. [http://dx.doi.org/10.1016/j.msec.2016.11.025] [PMID: 28024580]

[90] Lin H, Tang Y, Lozito TP, et al. Projection stereolithographic fabrication of BMP-2 gene-activated matrix for bone tissue engineering. Sci Rep 2017; 7(1): 11327. [http://dx.doi.org/10.1038/s41598-017-11051-0] [PMID: 28900122]

[91] Yeh YC, Highley CB, Ouyang L, Burdick JA. 3D printing of photocurable poly(glycerol sebacate) elastomers. Biofabrication 2016; 8(4): 045004.

[http://dx.doi.org/10.1088/1758-5090/8/4/045004] [PMID: 27716633]

[92] Zadpoor AA, Malda J. Additive manufacturing of biomaterials, tissues, and organs. Ann Biomed Eng 2017; 45(1): 1-11. [http://dx.doi.org/10.1007/s10439-016-1719-y] [PMID: 27632024]

[93] Cox SC, Thornby JA, Gibbons GJ, Williams MA, Mallick KK. 3D printing of porous hydroxyapatite scaffolds intended for use in bone tissue engineering applications. Mater Sci Eng C 2015; 47: 237-47. [http://dx.doi.org/10.1016/j.msec.2014.11.024] [PMID: 25492194]

[94] Mironov AV, Grigoryev AM, Krotova LI, Skaletsky NN, Popov VK, Sevastianov VI. 3D printing of PLGA scaffolds for tissue engineering. J Biomed Mater Res A 2017; 105(1): 104-9. [http://dx.doi.org/10.1002/jbm.a.35871] [PMID: 27543196]

[95] Dababneh AB, Ozbolat IT. Bioprinting technology: A current state-of-the-art review. J Manuf Sci Eng 2014; 136(6) [http://dx.doi.org/10.1115/1.4028512]

[96] Trombetta R, Inzana JA, Schwarz EM, Kates SL, Awad HA. 3D printing of calcium phosphate ceramics for bone tissue engineering and drug delivery. Ann Biomed Eng 2017; 45(1): 23-44. [http://dx.doi.org/10.1007/s10439-016-1678-3] [PMID: 27324800]

[97] Panayotov IV, Orti V, Cuisinier F, Yachouh J. Polyetheretherketone (PEEK) for medical applications. J Mater Sci Mater Med 2016; 27(7): 118. [http://dx.doi.org/10.1007/s10856-016-5731-4] [PMID: 27259708]

[98] Jensen J, Rölfing JHD, Le DQ, et al. Surface-modified functionalized polycaprolactone scaffolds for bone repair: In vitro and in vivo experiments. J Biomed Mater Res A 2014; 102(9): 2993-3003. [http://dx.doi.org/10.1002/jbm.a.34970] [PMID: 24123983]

[99] Xu N, Ye X, Wei D, et al. 3D artificial bones for bone repair prepared by computed tomography-guided fused deposition modeling for bone repair. ACS Appl Mater Interfaces 2014; 6(17): 14952-63. 
[http://dx.doi.org/10.1021/am502716t] [PMID: 25133309]

[100] Idaszek J, Bruinink A, Święszkowski W. Ternary composite scaffolds with tailorable degradation rate and highly improved colonization by human bone marrow stromal cells. J Biomed Mater Res A 2015; 103(7): 2394-404.

[http://dx.doi.org/10.1002/jbm.a.35377] [PMID: 25424876]

[101] Li Y, Wu ZG, Li XK, et al. A polycaprolactone-tricalcium phosphate composite scaffold as an autograft-free spinal fusion cage in a sheep model. Biomaterials 2014; 35(22): 5647-59.

[http://dx.doi.org/10.1016/j.biomaterials.2014.03.075] [PMID: 24743032]

[102] Christensen K, Xu C, Chai W, Zhang Z, Fu J, Huang Y. Freeform inkjet printing of cellular structures with bifurcations. Biotechnol Bioeng 2015; 112(5): 1047-55. [http://dx.doi.org/10.1002/bit.25501] [PMID: 25421556]

[103] Wengerter BC, Emre G, Park JY, Geibel J. Three-dimensional printing in the intestine. Clin Gastroenterol Hepatol 2016; 14(8): 1081-5. [http://dx.doi.org/10.1016/j.cgh.2016.05.008] [PMID: 27189913]

[104] Gu BK, Choi DJ, Park SJ, Kim MS, Kang CM, Kim C-H. 3-Dimensional bioprinting for tissue engineering applications. Biomater Res 2016; 20: 12 .

[http://dx.doi.org/10.1186/s40824-016-0058-2] [PMID: 27114828]

[105] Hernández-Córdova R, Mathew DA, Balint R, et al. Indirect three-dimensional printing: A method for fabricating polyurethane-urea based cardiac scaffolds. J Biomed Mater Res A 2016; 104(8): 1912-21. [http://dx.doi.org/10.1002/jbm.a.35721] [PMID: 26991636]

[106] Hasan A, Memic A, Annabi N, et al. Electrospun scaffolds for tissue engineering of vascular grafts. Acta Biomater 2014; $10(1)$ : 11-25. [http://dx.doi.org/10.1016/j.actbio.2013.08.022] [PMID: 23973391]

[107] Shafiee A, Atala A. Printing technologies for medical applications. Trends Mol Med 2016; 22(3): $254-65$. [http://dx.doi.org/10.1016/j.molmed.2016.01.003] [PMID: 26856235]

[108] Hasan A, Ragaert K, Swieszkowski W, et al. Biomechanical properties of native and tissue engineered heart valve constructs. J Biomech 2014; 47(9): 1949-63.

[http://dx.doi.org/10.1016/j.jbiomech.2013.09.023] [PMID: 24290137]

[109] Mandrycky C, Wang Z, Kim K, Kim DH. 3D bioprinting for engineering complex tissues. Biotechnol Adv 2016; $34(4)$ : 422-34. [http://dx.doi.org/10.1016/j.biotechadv.2015.12.011] [PMID: 26724184]

[110] Jakus AE, Rutz AL, Jordan SW, et al. Hyperelastic "bone": A highly versatile, growth factor-free, osteoregenerative, scalable, and surgically friendly biomaterial. Sci Transl Med 2016; 8(358): 358ra127. [http://dx.doi.org/10.1126/scitranslmed.aaf7704] [PMID: 27683552]

[111] Hung BP, Naved BA, Nyberg EL, et al. Three-Dimensional printing of bone extracellular matrix for craniofacial regeneration. ACS Biomater Sci Eng 2016; 2(10): 1806-16. [http://dx.doi.org/10.1021/acsbiomaterials.6b00101] [PMID: 27942578]

[112] Du Y, Liu H, Shuang J, Wang J, Ma J, Zhang S. Microsphere-based selective laser sintering for building macroporous bone scaffolds with controlled microstructure and excellent biocompatibility. Colloids Surf B Biointerfaces 2015; 135: 81-9. [http://dx.doi.org/10.1016/j.colsurfb.2015.06.074] [PMID: 26241919]

[113] C-H. Chen, Ming-Yih Lee, Victor Bong-Hang Shyu, Yi-Chieh Chen, Chien-Tzung Chen, Jyh-Ping Chen. Surface modification of polycaprolactone scaffolds fabricated via selective laser sintering for cartilage tissue engineering. Mater Sci Eng C 2014; 40(1): $389-97$.

[114] Roskies M, Jordan JO, Fang D, et al. Improving PEEK bioactivity for craniofacial reconstruction using a 3D printed scaffold embedded with mesenchymal stem cells. J Biomater Appl 2016; 31(1): 132-9. [http://dx.doi.org/10.1177/0885328216638636] [PMID: 26980549]

[115] Feng P, Wei P, Shuai C, Peng S. Characterization of mechanical and biological properties of 3-D scaffolds reinforced with zinc oxide for bone tissue engineering. PLoS One 2014; 9(1): e87755. [http://dx.doi.org/10.1371/journal.pone.0087755] [PMID: 24498185]

[116] Shuai C, Mao Z, Han Z, Peng S. Preparation of complex porous scaffolds via selective laser sintering of poly(vinyl alcohol)/calcium silicate. J Bioact Compat Polym 2014; 29: 110-20. [http://dx.doi.org/10.1177/0883911514522570]

[117] Muth JT, Dixon PG, Woish L, Gibson LJ, Lewis JA. Architected cellular ceramics with tailored stiffness via direct foam writing. Proc Natl Acad Sci USA 2017; 114(8): 1832-7. [http://dx.doi.org/10.1073/pnas.1616769114] [PMID: 28179570]

[118] Hollister SJ, Flanagan CL, Morrison RJ, et al. Integrating image-based design and 3D biomaterial printing to create patient specific devices within a design control framework for clinical translation. ACS Biomater Sci Eng 2016; 2: 1827-36. [http://dx.doi.org/10.1021/acsbiomaterials.6b00332]

[119] Shimomura K, Moriguchi Y, Ando W, et al. Osteochondral repair using a scaffold-free tissue-engineered construct derived from synovial mesenchymal stem cells and a hydroxyapatite-based artificial bone. Tissue Eng Part A 2014; 20(17-18): 2291-304 [http://dx.doi.org/10.1089/ten.tea.2013.0414] [PMID: 24655056] 
[120] Alexander PG, Gottardi R, Lin H, Lozito TP, Tuan RS. Three-dimensional osteogenic and chondrogenic systems to model osteochondral physiology and degenerative joint diseases. Exp Biol Med (Maywood) 2014; 239(9): 1080-95. [http://dx.doi.org/10.1177/1535370214539232] [PMID: 24994814]

[121] Lorber B, Hsiao W-K, Hutchings IM, Martin KR. Adult rat retinal ganglion cells and glia can be printed by piezoelectric inkjet printing. Biofabrication 2014; 6(1): 015001-10. [http://dx.doi.org/10.1088/1758-5082/6/1/015001] [PMID: 24345926]

[122] Pati F, Ha DH, Jang J, Han HH, Rhie JW, Cho DW. Biomimetic 3D tissue printing for soft tissue regeneration. Biomaterials 2015; 62: $164-75$.

[http://dx.doi.org/10.1016/j.biomaterials.2015.05.043] [PMID: 26056727]

[123] Irvine SA, Agrawal A, Lee BH, et al. Printing cell-laden gelatin constructs by free-form fabrication and enzymatic protein crosslinking. Biomed Microdevices 2015; 17(1): 16 [http://dx.doi.org/10.1007/s10544-014-9915-8] [PMID: 25653062]

[124] Choi M, Heo J, Yang M, Hong J. Inkjet printing-based patchable multilayered biomoleculecontaining nanofilms for biomedical applications. ACS Biomater Sci Eng 2017. [http://dx.doi.org/10.1021/acsbiomaterials.7b00138]

[125] Kwon J, Cho H, Eom H, et al. Low-temperature oxidation-free selective laser sintering of cu nanoparticle paste on a polymer substrate for the flexible touch panel applications. ACS Appl Mater Interfaces 2016; 8(18): 11575-82. [http://dx.doi.org/10.1021/acsami.5b12714] [PMID: 27128365]

[126] Jill Z, Manapat, Joey Dacula Mangadlao, et al. High-strength stereolithographic 3D printed nanocomposites: Graphene oxide metastability. ACS Appl Mater Interfaces 2017. [http://dx.doi.org/10.1021/acsami.6b16174]

\section{(C) 2018 Devi et al.}

This is an open access article distributed under the terms of the Creative Commons Attribution 4.0 International Public License (CC-BY 4.0), a copy of which is available at: (https://creativecommons.org/licenses/by/4.0/legalcode). This license permits unrestricted use, distribution, and reproduction in any medium, provided the original author and source are credited. 